Original Research Paper

\title{
Physicochemical Characteristics and Sub Chronic Oral Toxicity of Pistacia lentiscus L. Vegetable Oil in Rabbits
}

\author{
${ }^{1}$ Maameri Zineb, ${ }^{1,2}$ Zouhir Djerrou, ${ }^{3}$ Sofiane Habibatni, \\ ${ }^{1}$ Foulla Riachi, ${ }^{1}$ Hadria Djaalab and ${ }^{1}$ Youcef Hamdi Pacha \\ ${ }^{1}$ Laboratory of Pharmacology and Toxicology, University of Mentouri Constantine, Algeria \\ ${ }^{2}$ Department of Sciences of Nature and Life, Faculty of Sciences, University of August 20th 1955, Skikda, Algeria \\ ${ }^{3}$ Laboratory of Valorization of Natural Resources and Synthesis of Biologically Active Substances, \\ Faculty of Sciences, University of Mentouri Constantine, Algeria
}

\author{
Article history \\ Received: $30-12-2015$ \\ Revised: $11-01-2016$ \\ Accepted: 13-01-2016 \\ Corresponding Author: \\ Zouhir Djerrou \\ Department of Sciences of \\ Nature and Life, Faculty of \\ Sciences, University of August \\ 20th 1955, Skikda, Algeria \\ Email: zouhir21265@yahoo.fr
}

\begin{abstract}
Pistacia lentiscus vegetable oil is a well known natural product in Algerian traditional medicine. It is widely used in the treatment of back pain, respiratory problems and skin burns. The aim of this study was the determination of some physicochemical parameters and the investigation of sub-chronic oral toxicity of this fatty oil in rabbits. The physico-chemical parameters obtained for this oil were similar to those reported for similar oils [density: 0.915, refractive index: 1.46; acid value $(\mathrm{mg} \mathrm{KOH} / \mathrm{g}): 8.4$; saponification value $(\mathrm{mg} \mathrm{KOH} / \mathrm{g})$ : 187.5]. The sub-chronic toxicity test conducted in rabbits at different doses $\left(0.5,1\right.$ and $\left.2 \mathrm{~mL} \mathrm{~kg}^{-1}\right)$ for 28 days via oral route did not result in any signs of toxicity. The biochemicals results indicate that this oil maintain rates of ALT and AST in the physiological norms. A significant decrease in blood glucose was registered, but always within the physiological standards. Other experimental studies are required to accomplish the pharmacotoxicological profile of this vegetable oil which is in spreading use.
\end{abstract}

Keywords: Pistacia lentiscus L., Vegetable Oil, Physicochemical Characterization, Oral Toxicity, Rabbits

\section{Introduction}

Pistacia lentiscus L. (Anacardiaceae) is a dense shrub, with a strong characteristic odor and green leaves, growing in many Mediterranean countries (Zrira et al., 2003). In Algeria, it is found on any type of soil, subhumid and semi-arid and scattered along the coast and grows in diverse habitats along a climate gradient that varies in saline radiation, temperature and precipitation (Saadoune, 2005; Ait Said et al., 2011). The essential oil and gum of this plant have been widely used as a food and beverage additive in traditional medicines in the Mediterranean region since ancient times as the Greeks and the Egyptians, brought no toxicity in humans (Loutrari et al., 2006; Ghalem and Mohamed, 2009).

The vegetable oil of Pistacia lentiscus L. is edible oil extracted from the fruit of this plant. In Algeria, this oil is used by the population in traditional medicine as an antidiarrheal, as livestock feed component (Trabelsi et al., 2013), it is recommended for diabetics, treatment of stomach pain and in the case of circumcision (Hmimsa, 2004) and back pain (Bellakhdar, 1997). It is also widely used in the treatment of respiratory and dermal burns in
Algerian folk medicine (Djerrou et al., 2011). Scientifically tested, the oil has proved a real wound healing activity on experimental burns in the rabbit model, by reducing the inflammatory phase, promoting wound contraction and reducing the period of epithelialization (Djerrou et al., 2010), antihypercholesterolemic activity (Djerrou, 2014).

Despite the popular use of the vegetable oil of Pistacia lentiscus L., systematic assessment of toxic effects is almost absent, information of toxicity of this plant is very important as a reference point before exploring to continue to develop it as new herbal medicine (Tahraoui et al., 2010; Harizal et al., 2010). The aim of the present study is the investigation of some physico-chemical parameters of this oil and the evaluation to its sub-chronic oral toxicity in rabbits.

\section{Materials and Methods}

Measurements of Physicochemical Parameters of Vegetable Oil of Pistacia lentiscus L.

The determination tests of physicochemical parameters of the $P$. lentiscus fatty oil (organoleptic 
characteristics, density, refractive index, acidity and saponification index) has been made in a private laboratory of quality control in Constantine. The physicochemical parameters measured and the methods used for this analysis are summarized in Table 1.

Sub-Chronic Oral Toxicity of Vegetable Oil of Pistacia lentiscus L.

\section{Animals}

The sub-chronic toxicity test was carried out on New Zealand male rabbits (albino), weighing between $2,5-3 \mathrm{Kg}$ at the beginning of experience, from a farm in Ain M'Lila (northern Algeria). The animals were kept under standard individual cages in a standard environment with a temperature of $22 \pm 2{ }^{\circ} \mathrm{C}, 50-75 \%$ humidity and a cycle of $12 \mathrm{~h}$ light-dark light. Food and water were provided ad libitum.

\section{Experimental Design}

The study was performed on eighteen rabbits. After seven days of acclimatization in laboratory conditions, the animals were divided according to weight into three groups of six rabbits that were treated with $P$. lentiscus vegetable oil as follows:

- Group I (PLFO1): Received $0,5 \mathrm{~mL} \mathrm{~kg}^{-1}$

- Group II (PLFO2) received $1 \mathrm{~mL} \mathrm{~kg}^{-1}$

- Group III (PLFO3) received a dose of $2 \mathrm{~mL} \mathrm{~kg}^{-1}$

All treatments were done by the oral gavage, once daily for 28 days (Atsamo et al., 2011). The animals were observed on the change in general behavior and mortality for a period of 28 days.

\section{Biochemical Analysis}

Blood samples were collected in heparin tubes on the marginal ear vein of the rabbit at 0 and 28 th day.

Table 1. Determination of the physicochemical parameters of the oil

\begin{tabular}{ll}
\hline Determination & Methods \\
\hline 1-Organoleptic characters & \\
-Odeur and flavor & olfactory \\
-Aspect at $20^{\circ} \mathrm{C}$ & visual \\
-Color & visual \\
-Consistance & visual \\
-Hydrosolubility & visual \\
2-Acid index & Titration \\
3-Acidity & Titration \\
4- Refraction index & Refractometer \\
5-Density at $20^{\circ} \mathrm{C}$ & Pycnometric \\
6- Volatiles at $105^{\circ} \mathrm{C}$ & Gravimetric \\
7- Saponification index & Titration \\
\hline
\end{tabular}

Serum obtained by centrifugation at $3000 \mathrm{rpm}$ for $10 \mathrm{~min}$ was stored at $-20^{\circ} \mathrm{C}$ until use for analysis (Atsamo et al., 2011). Selected blood parameters were performed in the laboratory of biochemistry of the University Hospital of Batna by a biochemical analyzer (CI Architect 2800). The tested parameters were Aspartate Amino Transferase (AST), Alanine Amino Transferase (ALT), blood creatinine (CREA), the glucose (Glu) and urea.

\section{Statistical Data}

The results of biochemical parameters were expressed as mean with their variance. These data were compared by ANNOVA. The differences were considered significant at $\mathrm{p} \leq 0.05$.

\section{Results}

Physicochemical Parameters of the Vegetable Oil of Pistacia lentiscus $L$.

The physicochemical parameters of the vegetable oil of Pistacia lentiscus L. (Table 2) have revealed that this oil is a viscous liquid, oily, green in color, with odor and flavor characteristics. It is insoluble in water with a density of 0.915 , a refractive index of 1.464, saponification index of 187.5 and acid value of 8.5.

\section{Sub-Chronic Oral Toxicity of the Vegetable Oil of Pistacia lentiscus L.}

During the experimental period, all survived rabbits have remained healthy and they were available for evaluation.

\section{Clinical Signs and Body Weight Changes}

After administration of oil at doses $(0.5,1,2 \mathrm{~mL}$ $\mathrm{kg}^{-1}$ ), the animals showed no clinical symptoms of severe pain during the 28 days of observation, despite some usual clinical signs such as anorexia, hypoactivity and runny nose; this latter appeared in rabbits treated at a dose of $2 \mathrm{~mL} \mathrm{~kg}^{-1}$, at the 4 th days and that persisted until the end of the experiment with the death of a rabbit from the same group at 22 nd day; this death may be due to a bad manipulation.

\section{Biochemical Analysis}

Statistical analysis of biochemical parameters was recorded in the following Table (3-7). The liver enzyme levels were reduced in rabbits treated at doses ( 1 and 2 $\mathrm{mL} \mathrm{kg}^{-1}$ ) by the oil (PLFO).

The Aspartate Amino Transferase (AST) showed a significant reduction $(\mathrm{p}<0.05)$ in rabbits of groups II and III, while Alanine Amino Transferase (ALT) was not significantly reduced in the three treated groups 
by PLFO doses. In contrast, plasma glucose was significantly higher in rabbits of 1 st group $(0.5 \mathrm{~mL}$ $\mathrm{kg}^{-1}$ ) compared to lots II and III (1 and $2 \mathrm{~mL} \mathrm{~kg}^{-1}$ ).
For kidney indicators (urea and creatinine), the results showed disturbances in rabbits treated with different doses of PLFO.

Table 2. Physicochemical parameters of vegetable oil of Pistacia lentiscus L

\begin{tabular}{ll}
\hline Parameters & Results \\
\hline 1- Organoleptic characters & Characteristics \\
Odor and flavor & Not clear viscous liquid \\
Aspect at $20^{\circ} \mathrm{C}$ & Green \\
Color & oily \\
Consistance & insoluble \\
Hydrosolubility & 8.515 \\
2-Acid index $(\mathrm{mg} \mathrm{KOH} / \mathrm{g})$ & 8.5 \\
3-Acidity $(\mathrm{mg} \mathrm{KOH} / \mathrm{g})$ & 1.464 \\
4- Refraction index & 0.9154 \\
5-Density at $20^{\circ} \mathrm{C}\left(\mathrm{g} / \mathrm{cm}^{3}\right)$ & $0.20 \%$ \\
6-Volatiles at $105^{\circ} \mathrm{C}$ & 187.5 \\
7- Saponification index $(\mathrm{mg} \mathrm{KOH} / \mathrm{g})$ & \\
\hline
\end{tabular}

Table 3. Aspartateamino transaminase (IU/L) variations in rabbits treated with PLFO at different doses

\begin{tabular}{|c|c|c|c|c|c|}
\hline \multirow[b]{2}{*}{ Groups } & \multicolumn{2}{|l|}{ DO } & \multicolumn{2}{|l|}{ D28 } & \multirow{2}{*}{$\begin{array}{l}\text { ANOVA } \\
\text { (D0-D28) }\end{array}$} \\
\hline & $\mathrm{MN}$ & Variance & $\mathrm{MN}$ & Variance & \\
\hline $0.5 \mathrm{~mL} \mathrm{~kg}^{-1}$ (PLFO1) & 43.00 & 398.00 & 31.00 & 76.80 & NS \\
\hline $1 \mathrm{~mL} \mathrm{~kg}^{-1}(\mathrm{PLFO} 2)$ & 60.66 & 321.06 & 30.66 & 70.26 & $\mathrm{~S}$ \\
\hline $2 \mathrm{~mL} \mathrm{~kg}^{-1}$ (PLFO3) & 63.66 & 283.46 & 33.66 & 73.86 & S \\
\hline PLFO2 versus PLFO1 & NS & & NS & & \\
\hline PLFO3 versus PLFO1 & NS & & NS & & \\
\hline PLFO3 versus PLFO2 & NS & & NS & & \\
\hline
\end{tabular}

Table 4. Amino alanine transaminase (IU/L) variations in rabbits treated in PLFO at different doses

\begin{tabular}{|c|c|c|c|c|c|}
\hline \multirow[b]{2}{*}{ Groups } & \multicolumn{2}{|l|}{ DO } & \multicolumn{2}{|l|}{ D28 } & \multirow{2}{*}{$\begin{array}{l}\text { ANOVA } \\
\text { (DO-D28) }\end{array}$} \\
\hline & $\mathrm{MN}$ & Variance & $\mathrm{MN}$ & Variance & \\
\hline $0.5 \mathrm{~mL} \mathrm{~kg}^{-1}$ (PLFO1) & 26.00 & 143.6 & 43 & 299.2 & NS \\
\hline $1 \mathrm{~mL} \mathrm{~kg}^{-1}(\mathrm{PLFO} 2)$ & 34.33 & 802.6 & 30 & 51.20 & NS \\
\hline $2 \mathrm{~mL} \mathrm{~kg}^{-1}$ (PLFO3) & 39 & 560.0 & 28 & 62.00 & NS \\
\hline PLFO2 vs PLFO1 & NS & & NS & & \\
\hline PLFO3 vs PLFO1 & NS & & NS & & \\
\hline PLFO3 vs PLFO2 & NS & & NS & & \\
\hline
\end{tabular}

Table 5. Glycemia $(\mathrm{g} / \mathrm{L})$ variations in rabbits treated in PLFO at different doses

\begin{tabular}{|c|c|c|c|c|c|}
\hline \multirow[b]{2}{*}{$\begin{array}{l}\text { Groupes/ } \\
\text { GLU (g/L) }\end{array}$} & \multicolumn{2}{|l|}{$\mathrm{DO}$} & \multicolumn{3}{|l|}{ D28 } \\
\hline & MN & Variance & MN & Variance & $\begin{array}{l}\text { ANOVA } \\
\text { (DO-D28) }\end{array}$ \\
\hline $0.5 \mathrm{~mL} \mathrm{~kg}^{-1}$ (PLFO1) & 1.33 & 0.003 & 1.24 & 0.002 & $\mathrm{~S}$ \\
\hline $1 \mathrm{~mL} \mathrm{~kg}^{-1}$ (PLFO2) & 1.22 & 0.010 & 1.25 & 0.005 & NS \\
\hline $2 \mathrm{~mL} \mathrm{~kg}^{-1}$ (PLFO3) & 1.27 & 0.010 & 1.12 & 0.175 & NS \\
\hline PLFO2 vs PLFO1 & NS & & NS & & \\
\hline PLFO3 vs PLFO1 & NS & & NS & & \\
\hline PLFO3 vs PLFO2 & NS & & NS & & \\
\hline
\end{tabular}

Table 6. Creatinin $(\mathrm{mg} / \mathrm{L})$ variations in rabbits treated in PLFO at different doses

\begin{tabular}{|c|c|c|c|c|c|}
\hline \multirow[b]{2}{*}{ Groups } & \multicolumn{2}{|l|}{$\mathrm{DO}$} & \multicolumn{2}{|l|}{ D28 } & \multirow{2}{*}{$\begin{array}{l}\text { ANOVA } \\
\text { (DO-D28) }\end{array}$} \\
\hline & $\mathrm{MN}$ & Variance & $\mathrm{MN}$ & Variance & \\
\hline $0.5 \mathrm{~mL} \mathrm{~kg}^{-1}(\mathrm{PLFO} 1)$ & 11.33 & 0.666 & 15.16 & 0.566 & $\mathrm{~S}$ \\
\hline $1 \mathrm{~mL} \mathrm{~kg}^{-1}$ (PLFO2) & 10.66 & 0.666 & 15.33 & 1.466 & $\mathrm{~S}$ \\
\hline $2 \mathrm{~mL} \mathrm{~kg}^{-1}$ (PLFO3) & 11.66 & 1.466 & 13 & 4.000 & NS \\
\hline PLFO2 vs PLFO1 & NS & & NS & & \\
\hline PLFO3 vs PLFO1 & NS & & $\mathrm{S}$ & & \\
\hline PLFO3 vs PLFO2 & $\mathrm{NS}$ & & $\mathrm{S}$ & & \\
\hline
\end{tabular}


Table 7. Urea $(\mathrm{g} / \mathrm{L})$ variations in rabbits treated in PLFO at different doses

\begin{tabular}{|c|c|c|c|c|c|}
\hline \multirow[b]{2}{*}{ Groups } & \multicolumn{2}{|l|}{ D0 } & \multicolumn{2}{|l|}{ DE28 } & \multirow{2}{*}{$\begin{array}{l}\text { ANOVA } \\
\text { (D0-D28) }\end{array}$} \\
\hline & $\mathrm{MN}$ & Variance & $\mathrm{MN}$ & Variance & \\
\hline $0.5 \mathrm{~mL} \mathrm{~kg}^{-1}$ (PLFO1) & 0.23 & 0.006 & 0.706 & 0.1520 & $\mathrm{~S}$ \\
\hline $1 \mathrm{~mL} \mathrm{~kg}^{-1}$ (PLFO2) & 0.30 & $2^{\mathrm{E}-4}$ & 0.316 & 0.0029 & NS \\
\hline $2 \mathrm{~mL} \mathrm{~kg}^{-1}$ (PLFO3) & 0.37 & $5.6^{\mathrm{E}-4}$ & 0.266 & 0.0017 & $\mathrm{~S}$ \\
\hline PLFO2 vs PLFO1 & NS & & $\mathrm{S}$ & & \\
\hline PLFO3 vs PLFO1 & $\mathrm{S}$ & & S & & \\
\hline PLFO3 vs PLFO2 & $\mathrm{S}$ & & NS & & \\
\hline
\end{tabular}

\section{Discussion}

\section{Physicochemical Parameters of the Vegetable Oil of Pistacia lentiscus $L$.}

Determining various physicochemical indices, widely required by the pharmacopoeias, is interesting in terms of assessing the quality of vegetable oils (Bruneton, 2009).

The density depends on the temperature and chemical composition of the oil. It tells us about the nature of the fatty acid composition, particularly on the length of the chain, the presence of unsaturation and functionality on the carbon chain. The value of the density measured for this oil was $0.9154 \mathrm{~g} / \mathrm{cm}^{3}$. This value is consistent with the values reported by Boukeloua et al. (2012), namely a density in the range of $0.918 \pm 0.02$. The value is of the same order as those found in some vegetable oils; olive oil (0.910 to 0.916$)$, palm oil (0.895 to 0.900$)$, avocado oil (0.910 to 0.920) (Karleskind, 1992). However some vegetable oils, such as almond or argan, have lower densities, respectively equal to 0.906 and 0.9 (Maurin, 1992; Boudjira, 2002).

The refractive index is dependent, as the density of the oil composition and temperature. It increases with the presence of unsaturated fatty chains of secondary functions. The refractive index measured for the sample of this oil is 1.464. This value is closed to that reported by Boukeloua et al. (2012) for the same oil $(1.465 \pm 0.03)$ and those reported by Karleskind (1992), concerning olive oil, palm oil and avocado, which are respectively (1.468 to 1.470$)$ (1.453 to 1.458 ) and (1.464 to 1.474 ).

The acid index provides information on free fatty acids levels in the oil. This value for our sample was $8.515 \mathrm{mg} \mathrm{KOH} \mathrm{g}^{-1}$. This value is closed to that reported by Boukeloua et al. (2012) concerning this oil, which was 5.891 to 6.203 . Charef et al. (2008) have reported an acid values of $7.7 \pm 0.3$ and $24 \pm 0.5 \mathrm{mg} \mathrm{KOH} \mathrm{g}^{-1}$, for lentisk oil respectively extracted from black and red berries. The second value, relatively high compared to our sample (essentially of black color and ripe fruit), signaled by Charef et al. (2008), for red berries, not yet ripe, can be explained by the fact these berries contain a free fatty acid levels higher compared to ripe black berries.
The saponification index shows a value of 187.5 $\mathrm{mg} \mathrm{KOH} \mathrm{g}{ }^{-1}$ of oil. This value is closed to that reported by Boukeloua et al. (2012) (193.0 \pm 0.05 ), but it seems relatively higher than that obtained by Charef et al. (2008), with a saponification value of about $147.8 \pm 0.2$ for the oil extracted from the black fruit of $P$. lentiscus L. whereas for red fruits, this index is 154.6 \pm 0.1 . The saponification index of our sample of lentisk oil is much more consistent with the values reported for other oils. According to Karleskind (1992), plant oils as olive, palm and avocado respectively have saponification values of 184 to 196 , 190 to 205 and 177 to 198 .

\section{Sub-Chronic Oral Toxicity of the Vegetable Oil of Pistacia lentiscus L.}

In this study, the animals of the three groups had not presented severe pain. No significant difference was observed in the body weight of the three treatment groups and organ weights (Table 8).

When comparing the three animal groups, ANOVA revealed some variations in urea, creatinine and AST. While ALT and glucose have not changed significantly in the three treated groups.

In this study, liver function was assessed by measurement of transaminases (ALT and AST). The renal function was assessed by measuring the concentrations of urea and plasma creatinine (Baliga et al., 2004; Tahraoui et al., 2010; Harizal et al., 2010; Atsamo et al., 2011). Concerning the biochemical data, all blood biochemical parameters examined in this study were in physiological limits as reported by Quinton (2003). In addition, our results showed a significant decrease in concentrations of AST from D0 to D28 in the groups treated with 1 and $2 \mathrm{~mL} \mathrm{~kg}^{-1}$ body weight, these results agree with those found par Djerrou et al. (2011) in which the authors have tested the dose of 1 $\mathrm{mL} \mathrm{kg}{ }^{-1}$ via rectal route.

Blood glucose was decreased significantly in PLFO1 group $\left(0.5 \mathrm{~mL} \mathrm{~kg}^{-1}\right)$. At D28, no significant differences were noted between the different lots. However, these glycemia variations were within the range of physiological norms as was reported by Quinton (2003). 
Table 8. Organ weights (g) in rabbits treated in PLFO at different doses

\begin{tabular}{|c|c|c|c|c|c|c|c|c|c|c|}
\hline \multirow[b]{2}{*}{ Groups } & \multicolumn{2}{|l|}{ Liver } & \multicolumn{2}{|c|}{ Kidneys (2) } & \multicolumn{2}{|l|}{ Lungs } & \multicolumn{2}{|l|}{ Heart } & \multicolumn{2}{|c|}{ Spleens } \\
\hline & $\mathrm{MN}$ & Var & $\mathrm{MN}$ & Var & $\mathrm{MN}$ & Var & $\mathrm{MN}$ & Var & $\mathrm{MN}$ & Var \\
\hline $0.5 \mathrm{~mL} \mathrm{~kg}^{-1}$ (PLFO1) & 65.306 & 1.8140 & 15.023 & 2.518 & 11.233 & 0.256 & 7.955 & 0.123 & 1.520 & 0.161 \\
\hline $1 \mathrm{~mL} \mathrm{~kg}^{-1}$ (PLFO2) & 71.19 & 23.550 & 14.250 & 4.564 & 10.376 & 6.496 & 9.403 & 0.030 & 2.043 & 0.842 \\
\hline $2 \mathrm{~mL} \mathrm{~kg}^{-1}$ (PLFO3) & 61.43 & 72.346 & 15.060 & 4.733 & 11.32 & 4.027 & 7.853 & 1.352 & 1.890 & 0.166 \\
\hline PLFO2 vs PLFO1 & $\mathrm{S}$ & & NS & & NS & & S & & $\mathrm{S}$ & \\
\hline PLFO3 vs PLFO1 & NS & & NS & & NS & & NS & & NS & \\
\hline PLFO3 vs PLFO2 & $\mathrm{S}$ & & NS & & NS & & $\mathrm{S}$ & & NS & \\
\hline
\end{tabular}

For urea, comparison between different groups of the study showed that at day 0 , a non-significant increase between PLFO2 and PLFO1, but a significant increase between PLF1 and PLFO3 and also for PLFO3 and PLFO2. At D28, A significant decrease occurred between PLFO 2 and PLFO1 and also between PLFO1 and PLFO3. A no significant decrease was noted between PLFO2 and PLFO3. The comparison between D0-D28 has shown a significant increase in the dose 0.5 $\mathrm{mL} \mathrm{kg}^{-1}$ (PLFO1), but this increase was not significant at a dose of $2 \mathrm{~mL} \mathrm{~kg}^{-1}$ (PLFO3), against a significant reduction in the dose of $1 \mathrm{~mL} \mathrm{~kg}^{-1}$ (PLFO2). We note that these variations were within the range of physiological norms as was reported by Quinton (2003).

At the beginning of experimentation creatinine was significantly higher in the PLFO3 than in PLFO1 and PLFO3 compared to PLFO2 group. By cons, a nonsignificant decrease in PLFO2 compared to PLFO1 was registered. On D28, the results showed a significant increase between PLFO3 and PLFO1 and for lots PLFO3 and PLFO2 against a non-significant decrease between the lots PLFO1 and PLFO2. The comparison between D0-D28 showed a significant increase in the dose of 0.5 and $1 \mathrm{~mL} \mathrm{~kg}^{-1}$, against a non-significant increase in the dose of $2 \mathrm{~mL} \mathrm{~kg}$. However, the variations were in the range of physiological norms as was reported by Quinton (2003).

In this study, the oral administration of the vegetable oil of Pistacia lentiscus L. had not altered the biochemical parameters, except for a significant decrease in AST in 1 and $2 \mathrm{~mL} \mathrm{~kg}^{-1}$ doses finding a positive impact of this oil on liver function, a significant decrease in blood glucose at a dose of $0.5 \mathrm{~mL} \mathrm{~kg}^{-1}$ was recorded suggesting a possible hypoglycemic effect and some disturbances were recorded for renal function, but these variations were in physiological ranges.

Given the human dose of vegetable oil of $P$. lentiscus in Algerian traditional medicine, which is about two teaspoons to two tablespoons according to age (Djerrou et al., 2010), it is possible to assume that the traditional use of PLFO poses no risk of toxicity. Further long-term studies with graded doses and a high number of animals are needed to investigate the longterm side effects of this oil and to understand the variations occurred particularly for renal function.

\section{Conclusion}

The current study has provided certain information concerning the physicochemical aspects of Pistacia lentiscus vegetable oil. Such data could help to promote this product traditionally used in the treatment of wounds and burns. According to these results, this oil has a relative density and refractive index very close to results given for other vegetable oils. Its acidity and acid index are acceptable, compared to other values given by other authors for the same oil. A saponification index of 187.5, consistent with other values reported by other authors for the same oil. The study concludes also that oral doses tested for the vegetable oil of P. lentiscus L. may be considered as non toxic; they did not cause lethality, change in general behavior of animals or a significant disturbances in biochemical parameters.

\section{Acknowledgement}

The authors like to thank the technical staff of Biochemistry Laboratory (University Hospital of Batna) for their help in achieving the biochemical studies.

\section{Funding Information}

The authors have no support or funding to report.

\section{Author's Contributions}

Maameri Zineb: Participated in the different steps of the study.

Zouhir Djerrou: Participated in all experiments, statistical analysis and discussion and has drafted the manuscript.

Sofiane Habibatni: Participated in experimental study and results discussion.

Foulla Riachi and H Hadria Djaalab: Participated in experimental study.

Youcef Hamdi Pacha: Participated in interpretation of data.

\section{Ethics}

This article is original and contains unpublished material. The corresponding author confirms that all of the other authors have read and approved the manuscript and no ethical issues involved. 


\section{References}

Ait Said, S., C. Fernandez, S. Greff, F. Torre and A. Derridj et al., 2011. Inter-population variability of terpenoid composition in leaves of Pistacia lentiscus L. from Algeria: A chemoecological approach. Molecules, 16: 2646-2657. DOI: $10.3390 /$ molecules 16032646

Atsamo, A.D., T.B. Nguelefack, J.Y. Datté and A. Kamany, 2011. Acute and subchronic oral toxicity assessment of the aqueous extract from the stem bark of Erythrina senegalensis DC (Fabaceae) in rodents. J. Ethnopharmacol., 134: 697-702.

DOI: 10.1016/j.jep.2011.01.023

Bellakhdar, J., 1997. La Pharmacopée Marocaine Traditionnelle: Médecine Arabe Ancienne et Savoirs Populaires. 1st Edn., na, ISBN-10: 291072803X, pp: 764.

Boudjira, M., 2002. Contribution à l'étude Biochimiques de l'huile d'Arganier (Arganiaspinosa L.). Mem. Ing. Agro.

Boukeloua, A., A. Belkhiri, Z. Djerrou, L. Bahri and N. Boulebda et al., 2012. Acute toxicity of Opuntia ficus indica and Pistacia lentiscus seed oils in mice. Afr. J. Tradit. Complement Altern Med., 9: 607-611. PMID: 23983398

Bruneton, J., 2009. Pharmacognosie, Phytochimie, Plantes Médicinales. 4th Edn., Lavoisier, ISBN-10: 2743019042, pp: 1292.

Charef, M., M. Yousfi, M. Saidi and P. Stocker, 2008. Determination of the fatty acid composition of acorn (Quercus), Pistacia lentiscus seeds growing in Algeria. J. Am. Oil Chem. Soc., 85: 921-924. DOI: $10.1007 / \mathrm{s} 11746-008-1283-1$

Djerrou, Z., 2014. Anti-hypercholesterolemic effect of Pistacia lentiscus fatty oil in egg yolk-fed rabbits: A comparative study with simvastatin. Chinese J. Natural Med., 12: 561-566. DOI: $10.1016 / \mathrm{S} 1875-5364(14) 60086-8$

Djerrou, Z., Y. Hamdi-Pacha, A.M. Belkhiri, H. Djaalab and F. Riachi et al., 2011. Evaluation of Pistacia lentiscus fatty oil effects on glycemic index, liver functions and kidney functions of New Zealand rabbits. Afr. J. Tradit. Complement Altern Med., 8: 214-219. PMID: 22754077

Djerrou, Z., Z. Maameri, Y. Hamdo-Pacha, M. Serakta and F. Riachi et al., 2010. Effect of virgin fatty oil of Pistacia lentiscus on experimental burn wound's healing in rabbits. Afr. J. Trad. CAM., 7: 258-263. DOI: 10.4314 /ajtcam.v7i3.54788
Ghalem, B.R. and B. Mohamed, 2009. Antimicrobial activity evaluation of the oleoresin oil of Pistacia vera L. Afr. J. Pharmacy Pharmacol., 3: 092-096.

Harizal, S.N., S.M. Mansor, J. Hasnan, J.K.J. Tharakan and J. Abdullah, 2010. Acute toxicity study of the standardized methanolic extract of Mitragyna speciosa Korth in Rodent. J. Ethnopharmacol., 131: 404-409. DOI: 10.1016/j.jep.2010.07.013

Hmimsa, Y., 2004. L'agro biodiversité dans les agro systèmes traditionnels de montagnes: Cas du Rif marocain. Université Abdelmalek Essaâdi, Faculté des Sciences, Tétouan, Maroc.

Karleskind, A., 1992. Manuel Des Corps Gras. 1st Edn., Technique et Documentation-Lavoisier, Paris, ISBN-10: 2852066629, pp: 787.

Loutrari, H., S. Magkouta, A. Pyriochou, V. Koika and F.N. Kolisis et al., 2006. Mastic oil from Pistacia lentiscus var. chia inhibits growth and survival of human K562 leukemia cells and attenuates angiogenesis. Nutr. Cancer, 55: 86-93. PMID: 16965245

Baliga, M.S., G.C. Jagetia, J.N. Ulloor, M.P. Baliga and P. Venkatesh et al., 2004. The evaluation of the acute toxicity and long term safety of hydroalcoholic extract of Sapthaparna (Alstonia scholaris) in mice and rats. Toxicol. Lett., 151: 317-326. DOI: 10.1016/j.toxlet.2004.01.015

Maurin, R., 1992. L'Huile d'argan Argania spionsa L. Skeels Sapotaceae. Revue Française Des Corps Gras, 5-6: 139-145.

Quinton, J.F., 2003. Nouveaux animaux de Compagnie: Petites Mamifères. 1st Edn., Maloine, pp: 66.

Saadoune, N.S., 2005. Types stomatiques du genre Pistacia: Pistacia atlantica Desf. ssp. Atlantica et Pistacia lentiscus L.

Tahraoui, A., Z.H. Israili and B. Lyoussi, 2010. Acute and sub-chronic toxicity of lyophilized aqueous extract of Centaurium erythraea in rodents. J. Ethnopharmacol., 132: 48-55.

Trabelsi, H., J. Renaud, W. Herch, M.L. Khouja and S. Boukhchina et al., 2013. LC-ESI-QTOF-MS, MS/MS Analysis of glycerophospholipid species in three Tunisian Pistacia lentiscus fruit populations. J. Am. Oil Chemists' Society, 90: 611-618. DOI: $10.1007 / \mathrm{s} 11746-013-2203-6$

Zrira, S., A. Elamrani and B. Benjilali, 2003. Chemical composition of the essential oil of Pistacia lentiscus $L$. from Morocco-A seasonal variation. Flavour Fragrance J., 18: 475-480. DOI: 10.1002/ffj.1221 